\title{
ВЗАИМОДЕЙСТВИЕ ВЛАСТИ И БИЗНЕСА В КОНТЕКСТЕ РАЗВИТИЯ РЫНОЧНОЙ ЭКОНОМИКИ
}

\section{INTERACTION OF GOVERNMENT AND BUSINESS IN THE CONDITIONS OF THE MARKET ECONOMY}

\section{S. Asatryan}

Summary: The article examines the features of building relations between government and business in the context of the development of market relations. Analyzed and described effective tools and methods of cooperation. Attention is also focused on the need to expand the social base of interaction between state and business structures. The key aspects of building an effective public-private partnership in the context of globalization are outlined.

Keywords: business, partnership, power, partnership.
$\mathrm{B}$ современных рыночных условиях, характеризующихся экономической турбулентностью, участившимися финансовыми кризисами, а также интенсификацией процессов интеграции хозяйственных систем на различных уровнях все больше осознается необходимость конструктивного диалога между бизнесом и публичной властью.

В последние годы во всем мире наблюдается тенденция усиления сотрудничества государства и предпринимательских структур. Соответственно в процессе развития рыночных отношений бизнес постепенно занимает свойственное ему место в экономике [1]. Но, в тоже время, необходимо отметить, что в некоторых странах еще слабо развита система взаимодействия органов публичной власти и бизнеса и это пока не позволяет частному сектору эффективно реализовывать свои функции, а также негативно сказывается на решении как экономических, так и социальных проблем в стране.

Исходя из вышесказанного, выбранная тема статьи является актуальной и практически значимой.

В процессе анализа современных моделей и механизмов взаимодействия органов государственной власти и бизнес-структур представляют интерес различные управленческие аспекты их сотрудничества с учетом влияния на социально-экономические системы и процессы. В тоже время, несмотря на имеющиеся научные достижения, в настоящее время отсутствует комплексное исследование использования различных моделей государственно-частного партнерства, обоснование оп-
Асатрян Севак Размикович

Аспирант, НОЧУ ВО «Московский ФинансовоПромышленный Университет «Синергия» Scolak1@me.com

Аннотация: В статье рассматриваются особенности выстраивания отношений власти и бизнеса в условиях развития рыночных отношений. Проанализированы и описаны эффективные инструменты и методы сотрудничества. Также акцентировано внимание на необходимости расширения социальной базы взаимодействия государственных и предпринимательских структур. 0бозначены ключевые аспекты построения эффективного государственночастного партнерства на уровне регионов и условиях глобализации.

Ключевые слова: бизнес, партнерство, власть, партнерство.

тимальных форм их сотрудничества в процессе реализации стратегических общественных и частных инициатив.

Таким образом, с учетом вышеизложенного, цель статьи заключается в изучении особенностей взаимодействия власти и бизнеса в условиях рыночной экономики.

Прежде всего, следует отметить, что основу построения системы отношений государства и бизнеса в условиях рыночной экономики составляет постулат, суть которого заключается в том, что государство не может реализовывать свои социально-экономические функции без эффективно работающего предпринимательского сектора, а последний в свою очередь, не может активно развиваться без поддержки государства [2].

По мнению автора, эффективными инструментами взаимодействия власти и бизнеса в условиях рыночной экономики являются:

1. Привлечение представителей власти всех уровней, союзов предпринимателей к обсуждению проблем предпринимательства, разработка предложений органами государственной власти, местного самоуправления для создания соответствующего правового поля и локальных нормативно-правовых актов по развитию предпринимательства (специальные режимы налогообложения, финансирование и кредитование малого бизнеса, трудовые отношения и социальная защита и т.д.), включение союзов предпринимателей в нормотворческую деятельность.

2. Введение специальных режимов инвестиционной 
деятельности с целью стимулирования ускоренного развития территорий с уникальными преимуществами.

3. Активная деятельность региональных и местных органов власти по стимулированию малого и среднего бизнеса.

4. Налаживание эффективной и качественной деятельности центров предоставления административных услуг.

5. Использование финансового лизинга как инструмента развития населенных пунктов.

6. Прозрачность деятельности власти и постоянное информирование о налоговых обязанностях, упрощенные процедуры налогообложения.

Представляется целесообразным обратить внимание на тот факт, что в процессе управления и выстраивания взаимоотношений власти с бизнесом, кроме единых национальных основ также следует учитывать региональные аспекты, обусловленные спецификой местных возможностей и условий их реализации.

Выбор путей и механизмов достижения партнерства бизнеса и государства в регионах является актуальной задачей регионального развития как страны в целом, так и ее территорий. Региональный бизнес сосредотачивает значительные финансовые и материальные ресурсы, управленческий и кадровый потенциал, прогрессивные организационно-управленческие и финансовые технологии. Именно поэтому обоснование направлений их рационального использования во многих вопросах определяет возможности развития экономики регионов и решения их социальных проблем.

Отдельный акцент необходимо сделать на особенностях взаимодействия власти и бизнеса в условиях глобализации и интеграции экономических отношений, а также с учетом постепенного стирания границ между регионами, странами, отдельными территориями.

В данном контексте целесообразно отметить, что эффективное государственно-частное партнерство, в результате взаимопроникновения внутригосударственных и международных товарно-финансовых потоков, выступает инструментом укрепления хозяйственных, территориальных и социальных взаимосвязей между странами и отдельными частями экономического пространства внутри страны. С усилением межгосударственных экономических взаимоотношений появляются возможности по привлечению наряду с отечественным также и частного иностранного капитала для финансирования инфраструктурных сетей, магистральных трубопроводов, морских и воздушных портов, систем водо-, газо-, тепло-, энергоснабжения. Ведь уровень развития инфраструктуры влияет на инвестиционную привлекательность других сфер хозяйства, деловую финансовую активность бизнеса, его конкурентоспособность на мировом рынке и готовность предпринимательских структур к участию в международной кооперации.

Очерчивая перспективы и векторы будущего развития сотрудничества власти и бизнеса, необходимо обратить внимание на тот факт, что за прошедшие два десятилетия в их отношениях произошли существенные изменения. На первый план вышли принципиально новые формы взаимодействия. В государственных структурах постепенно приходит понимание того, что жесткое регулирование и налоги не генерируют рост общественного благосостояния. Акценты во взаимодействии с частным сектором постепенно смещаются в сторону добровольного саморегулирования. С другой стороны, частный сектор постепенно переходит от бессистемной благотворительности к более сложным, стратегическим формам взаимодействия с правительством.

С учетом вышеизложенного, целесообразно, чтобы эффективное сотрудничество вышеупомянутых субъектов характеризовалось благоустройством отношений между государством и бизнесом путем применения экономических рычагов, развития морального фактора, норм правовой и социальной ответственности.

Таким образом, подводя итоги, отметим, что рыночная экономика формирует высокий потенциал для развития различных форм государственно-частного партнерства, реализация которого требует системного подхода в управлении процессами экономического взаимодействия бизнеса и государства.

\section{ЛИТЕРАТУРА}

1. Закирова А.Э. Взаимодействие властных структур и предпринимательства: зарубежный опыт и отечественные реалии // Азимут научных исследований: экономика и управление. 2018. №2(23). С. 151-153.

2. Government-business relations and regional development in post-reform Mexico / Theodore Kahn, Hampshire: Palgrave Macmillan, 2018.345 p.

(c) Асатрян Севак Размикович (Scolak1@me.com). 